\title{
STUDI DESKRIPTIF MENGENAI SOFT SKILLS PADA MAHASISWA DI POLMAN BANDUNG
}

Emma Dwi Ariyani

Unit Sosio Manufaktur, Politeknik Manufaktur Negeri Bandung, J1. Kanayakan No.21 Bandung Email:emma@polman-bandung.ac.id

\begin{abstract}
ABSTRAK. Penelitian ini bertujuan untuk memperoleh gambaran mengenai soft skills pada mahasiswa dan faktor-faktor yang berperan dalam penguasaan keterampilan tersebut. Penelitian diikuti oleh mahasiswa tingkat II di Politeknik Manufaktur Negeri Bandung (Polman Bandung) yang terdiri dari 22 mahasiswi dan 97 mahasiswa. Dengan mengunakan metode penelitian deskriptif dan alat ukur soft skills yaitu soft competency questionnaire-self assessment (SCQ-SA) mengukur enam aspek soft skills yaitu motivation, flexibility, willingness to learn, integrity, relationship building dan teamwork \& cooperation. Penelitian ini menemukan bahwa gambaran umum soft skills partisipan penelitian tergolong cukup (median $=3$ ). Diantara keenam aspek tersebut, aspek flexibility yaitu keterampilan untuk beradaptasi merupakan aspek yang lebih dikuasai oleh partisipan dibandingkan aspek-aspek yang lain. Penelitian ini juga menggali permasalahan yang sering dihadapi mahasiswa yaitu masalah motivasi, relasi dengan teman, dan kemauan untuk selalu ingin belajar. Pengujian terhadap perbedaan soft skills di antara perempuan dan laki-laki menunjukkan bahwa jenis kelamin tidak memiliki peran yang signifikan terhadap penguasaan soft skills pada mahasiswa.
\end{abstract}

Kata kunci: gambaran, soft skills, mahasiswa

\section{DESCRIPTIVE STUDY ON STUDENTS'SOFT SKILLS AT POLMAN BANDUNG}

ABSTRACT. This study is aimed to describe students'soft skills and the factors that play roles in the mastery of these skills. The study followed by students from grades II Politeknik Manufaktur Negeri Bandung (Polman Bandung) consisting of 22 female and 97 male. Using descriptive research methods and soft skills measurement namely soft competency questionnaire-self assessment (SCQ-SA), measured six aspects of soft skills that are motivation, flexibility, willingness to learn, integrity, relationship building and teamwork \& cooperation. This study found that the participants have a moderate degree of soft skills (median =3). Among the six aspects of soft skills, the aspect of flexibility is the aspect which is more skilled by the participant. The study also explored the problems often faced by students. It was found that motivation, relationship problems with friends and willingness to learn are often faced by students. Some examination of the differences between soft skills of female and male showed that gender has no a significant role to the mastery of soft skills in student.

Keywords: description, soft skills, student

\section{PENDAHULUAN}

Dalam rangka melaksanakan ama-nah Undang-undang Dasar Negara Re-publik Indonesia Tahun 1945, Pasal 31 ayat (3) menyatakan bahwa "Pemerintah mengusahakan dan menyelenggarakan satu sistem pendidikan nasional, yang me-ningkatkan keimanan dan ketakwaan serta akhlak mulia dalam rangka mencerdaskan kehidupan bangsa yang diatur dengan undang-undang" kemudian ditetapkan Undang-undang Republik Indonesia Nomor 20 Tahun 2003 tentang Sistem Pendidikan Nasional.

Pada pasal 3 dalam UU No 20 tahun 2003 dijelaskan Pendidikan nasional berfungsi mengembangkan kemampuan dan membentuk watak serta peradaban bangsa yang bermartabat dalam rangka mencerdaskan kehidupan bangsa, bertujuan untuk berkembangnya potensi peserta didik agar menjadi manusia yang beriman dan bertakwa kepada Tuhan Yang Maha Esa, berakhlak mulia, sehat, berilmu, cakap, kreatif, mandiri, dan menjadi warga negara yang demokratis serta bertanggungjawab.

Dalam perspektif karakter individu dengan menggunakan pendekatan psikologis, karakter bangsa yang terdapat dalam setiap sila ditempatkan dalam kerangka referensi olah hati, olah pikir, olah raga, olah rasa dan karsa. Muatan dari keempat olah tersebut dijabarkan seperti yang tercantum dalam Kebijakan Nasional, Pembangunan Karakter Bangsa, Tahun 2010-2025. Muatan karakter 
yang berasal dari olah hati, olah pikir, olah raga, olah rasa dan karsa yang diturunkan dari setiap sila Pancasila, kemudian dipilih satu jenis karakter dari keempat olah tersebut. Adapun berbagai macam jenis karakter dan karakter yang dipilih sebagai nilai-nilai dasar karakter yang diberlakukan di lingkungan Dikti adalah jujur, cerdas, tangguh, dan peduli.

Politeknik Manufaktur Negeri Bandung (Polman Bandung) sebagai salah satu perguruan tinggi negeri di Indonesia juga memiliki sasaran yang sama untuk menyiapkan lulusannya memiliki karakter yang jujur, cerdas, tangguh dan peduli. Dalam profil lulusan Polman Bandung terkandung 4 karakter yang telah dicanangkan Dikti serta dilengkapi dengan karakter iman dan taqwa kepada Tuhan YME, jiwa wirausaha dan karakter adaptasi terhadap lingkungan dan teknologi. Untuk menyiapkan para mahasiswanya memiliki karakter tersebut, berbagai upaya pembinaan karakter dilakukan melalui program intra-kurikuler dan program kegiatan kemahasiswaan seperti kokurikuler, ekstra-kurikuler serta program kesejahteraan dan kepedulian mahasiswa.

Pembinaan karakter yang dilakukan di Polman Bandung melalui beberapa tahapan seperti input merupakan tahapan penyeleksian penerimaan mahasiswa, tahap proses merupakan tahapan pembinaan karak-ter selama menjadi mahasiswa di Polman Bandung dan terakhir tahap output yaitu tahapan dimana mahasiswa telah selesai dengan pendidikan dan siap memasuki dunia kerja. Dimana pada setiap tahapan tersebut diperlukan sebuah pengukuran soft skills sebagai data dan bahan evaluasi dalam pembinaan karakter mahasiswa yang diterapkan.

Pengukuran soft skills yang telah dilakukan dengan bekerja sama dengan provider biro konsultasi di Bandung, menitik beratkan pada 6 aspek soft competency yaitu motivation, flexibility, willingness to learn, integrity, relationship building dan teamwork
\& cooperation. Penelitian ini mencoba menggambarkan hasil pengukuran soft skills mahasiswa dalam upaya pembinaan karakter mahasiswa di Polman Bandung.

Soft skills adalah seperangkat kemampuan yang mempengaruhi bagaimana kita berinteraksi dengan orang lain. Soft skills memuat komunikasi efektif, berpikir kreatif dan kritis, membangun tim, serta kemampuan lainnya yang terkait kapasitas kepribadian individu (Widhiarso, 2009). Soft skills merupakan kemampuan yang tidak tampak dan seringkali berhubungan dengan emosi manusia. Terdapat peta atribut personal yang menggambarkan atribut dari kompetensi hingga moral individu dalam sebuah kontinum. Soft skills terletak antara perilaku individu dan keterampilan pengelolaan diri. Intervensi yang dapat diberikan dalam meningkatkan soft skills adalah dengan pelatihan atau dengan pembinaan yang intensif. Pengukuran soft skills merupakan media untuk mendapatkan informasi ten-tang kondisi soft skills mahasiswa dan mengantisipasi kondisi yang ada untuk dapat membuat strategi pembinaan karakter mahasiswa sesuai sasaran.

Penelitian yang telah ada sebelumnya, menunjukkan besarnya peranan karakteristik personal sebagai prediktor dominan terhadap kesuksesan individu dalam kehidupannya. Seperti misalnya pada hasil penelitian Barrick, dkk (2001) menyimpulkan bahwa faktor ketahanan pribadi dan kestabilan emosi yang merupakan karakteristik personal menjadi prediktor yang paling besar terhadap kesuksesan dalam bekerja secara umum.

Namun demikian penelitian yang berhubungan dengan pengukuran soft skills masih minim dilakukan. Jika kita mengakses internet dan mengetik "emotional intelligence test" pada mesin pencari google, maka kita temukan sejumlah alat ukur kecerdasan emosional tersebut. Tetapi kita akan mengalami kesulitan mendapatkan alat ukur soft skills. Konsultan pengembangan SDM internasional terkenal bernama Hay Group yang sering dipakai perusahaanperusahaan besar di dunia dan juga yang 
mensponsori riset-riset Daniel Goleman tidak menyebut test-test yang ditampilkannya di situsnya sebagai test soft skills melainkan test kecerdasan emosional. Ini menandakan bahwa kajian-kajian ilmiah dan temuan riset tentang soft skills masih minim dan masih berpeluang luas untuk dikaji secara ilmiah (www.uin-malang.ac.id ; diakses 22 April 2013). Dengan dasar penelitian tersebut maka penelitian ini berupaya untuk memperoleh gambaran mengenai soft skills pada mahasiswa dan faktor-faktor yang berperan dalam penguasaan keterampilan tersebut.

\section{Kepribadian}

Ketika kita membicarakan tentang kepribadian, kita tidak bermaksud untuk membahas tentang seseorang yang memiliki kharisma, perilaku yang sopan, wajah yang selalu tersenyum, atau seorang finalis dalam sebuah kontes kecantikan yang memenangkan kategori puteri persahabatan karena kepribadiannya yang ramah dan mudah bergaul dan akrab dengan peserta lainnya.

Kemudian apabila dibawa ke dalam ranah organisasi, apakah kepribadian juga memiliki peran yang penting? Jika kita menanyakan hal tersebut kepada orangorang yang menghabiskan waktunya sebagai pegawai dalam sebuah organisasi atau pernah bekerja dalam tim, maka biasanya secara spontan mereka akan menyatakan persetujuannya bahwa faktor kepribadian memang memiliki peranan penting dalam sebuah organisasi. Jadi, sebenarnya apakah yang dimaksud dengan kepribadian itu?

Personality atau kepribadian berasal dari Bahasa Latin yaitu dari kata persona yang berarti topeng (mask). Berdasarkan asal kata tersebut, kepribadian diartikan sebagai kesan yang ingin kita tunjukkan kepada orang lain, atau dengan kata lain kepribadian ibarat topeng yang ingin kita tampilkan kepada dunia luar. Secara teori, definisi mengenai kepribadian yang paling sering digunakan adalah definisi yang dibuat oleh Allport (dalam Robbins, 2001) yang menyatakan bahwa kepribadian adalah suatu organisasi yang dinamis yang terdapat di dalam diri individu yang berupa sistem psychophysical yang menentukan bagaimana keunikan individu tersebut dalam beradaptasi dengan lingkungannya. Definisi tersebut menekankan pada atribut eksternal seperti peran individu dalam lingkungan sosial, penampilan individu, dan reaksi individu terhadap orang lain. Untuk itu, kita harus berpikir bahwa kepribadian adalah keseluruhan cara yang digunakan oleh individu dalam memberikan reaksi dan berinteraksi dengan individu yang lain. Sementara itu, Feist \& Feist (1998) mendefinisikan kepribadian sebagai sebuah pola yang relatif menetap, trait, disposisi atau karakteristik di dalam individu yang memberikan beberapa ukuran yang konsisten tentang perilaku (dalam Mastuti, 2005).

\section{Soft Skills}

Soft skill adalah istilah sosiologis yang berkaitan dengan "EQ" (Emotional Intelligence Quotient) seseorang, karakter kepribadian, interaksi sosial, komunikasi, bahasa, kebiasaan pribadi, keramahan, dan optimisme yang menjadi ciri seseorang dalam berhubungan dengan orang lain (en. wikipedia.org; diakses 22 April 2013)

Soft skills adalah seperangkat kemampuan yang mempengaruhi bagaimana kita berinteraksi dengan orang lain. Soft skills memuat komunikasi efektif, berpikir kreatif dan kritis, membangun tim, serta kemampuan lainnya yang terkait kapasitas kepribadian individu (Widhiarso, 2009). Kemampuan yang dimiliki manusia dapat diibaratkan gununges (ice berg), yang tampak diluar permukaan air adalah Hard skills atau Technical skills. Sedangkan kemampuan yang berada di bawah permukaan air dan memiliki porsi paling besar adalah Soft skills. Soft skills merupakan kemampuan yang tidak tampak dan seringkali berhubungan dengan emosi manusia.

Terdapat peta atribut personal yang menggambarkan atribut dari kompetensi hingga moral individu dalam sebuah kontinum. Soft skills terletak antara perilaku individu dan keterampilan pengelolaan 
diri. Intervensi yang dapat diberikan dalam meningkatkan soft skills adalah dengan pelatihan atau dengan pembinaan yang intensif.

Soft skills memiliki banyak variasi yang di dalamnya termuat elemen-elemen. Widhiarso (2009) menyebutkan bahwa berdasarkan hasil-hasil penelitian, beberapa elemen berikut ini dikaitkan dengan kesuksesan dalam dunia kerja, yaitu

\section{Kecerdasan Emosi}

Melalui penelitian Goleman (1998) menemukan bahwa kesuksesan seseorang tidak hanya didukung oleh seberapa pandai seseorang dalam menerapkan pengetahuan dan mendemonstrasikan keterampilannya, akan tetapi seberapa besar seseorang mampu mengelola dirinya dan interaksi dengan orang lain. Keterampilan tersebut dinamakan dengan kecerdasan emosi. Kecerdasan emosi juga meliputi sejumlah ke-terampilan yang berhubungan dengan keakuratan penilaian tentang emosi diri dan orang lain, dan kemampuan me-ngelola perasaan untuk memotivasi, merencanakan dan meraih tujuan hidup

\section{Gaya Hidup Sehat}

Marchand, dkk (2005) menemukan bahwa uang banyak terbuang dengan percuma oleh institusi dan masyarakat karena faktor minimnya produktivitas, pelayanan kesehatan, kecelakaan kerja, dan pegawai yang absen dalam bekerja. Pendukung utama dari sekian indikator tersebut adalah gaya hidup individu yang tidak sehat. Hasil penelitian menunjukkan gaya hidup yang sehat mempengaruhi tingginya ketahanan, fleksibilitas dan konsep diri yang sehat yang mempengaruhi tingginya partisipasi dalam komunitas

\section{Komunikasi Efektif}

Cangelosi dan Peterson (1998) menemukan bahwa banyak kegagalan siswa di sekolah, masyarakat dan tempat kerja diakibatkan karena rendahnya keterampilan dalam berkomunikasi. Secara tidak langsung keterampilan komunikasi mempengaruhi tingkat kepercayaan diri dan dukungan sosial yang kemudian dilanjutkan pengaruhnya ke kesuksesan.
Soft skills memuat banyak sekali variasi dan jenisnya. Institusi perlu menetapkan terlebih dahulu jenis soft skills yang akan dikembangkan. Pada penelitian ini dilakukan pula kajian aspek-aspek soft skills mana yang relevan dan sesuai dengan kebutuhan pembinaan karakter mahasiswa di Polman Bandung.

\section{METODE}

Metode penelitian yang digunakan pada penelitian ini adalah metode penelitian deskriptif yaitu suatu metode yang digunakan untuk memberikan gambaran tentang suatu keadaan pada saat penelitian berlangsung.

Alat ukur yang dipergunakan untuk mendapatkan gambaran soft skills mahasiswa adalah alat ukur soft skills yang dikembangkan oleh salah satu provider biro konsultasi psikologi di Bandung yang diberi nama soft competency questionnaire-self assessment (SCQ-SA) untuk mengukur 6 aspek soft skills yaitu motivation, flexibility, willingness to learn, integrity, relationship building dan team work \& cooperation. Dengan definisi operasional setiap aspek adalah sebagai berikut :

- Motivation adalah energi dan dorongan untuk bekerja keras, belajar dengan baik dan bila perlu melampaui target prestasi. Standar tersebut bisa berupa prestasi diri sendiri di masa lampau, ukuran objektif yang ditetapkan institusi, melebihi orang lain, sasaran yang menantang atau sesuatu yang belum pernah dilakukan oleh orang lain.

- Flexibility adalah kemampuan untuk beradaptasi dan belajar dengan efektif dalam situasi yang berbedam dan dengan berbagai individu atau kelompok.

- Willingness to learn adalah kemauan dan kemampuan untuk selalu ingin belajar yang diawali dengan adanya kesadaran akan kebutuhan mengembangkan diri, kemudian melakukan instrospeksi diri akan kelebihan dan kekurangannya dengan melihat tuntutan yang selalu berubah dan meningkat.

- Integrity adalah bertindak konsisten, komit serta menunjukkan kejujuran yang sesuai dengan nilai-nilai dan kebijakan 
institusi serta kode etik walaupun dalam keadaan yang sulit untuk melakukan ini.

- Relationship building adalah melakukan kegiatan untuk membangun dan memelihara jaringan, kontak dengan orang yang berguna atau yang mungkin berguna dalam pencapaian tujuan studi. Kompetensi ini didasari oleh interpersonal skill termasuk di dalamnya unsur keyakinan diri dan kepedulian akan lingkungan sosial.

- Team work \& cooperation adalah keinginan untuk bekerja sama melalui suatu jalinan komunikasi dengan orang lain secara kooperatifdan menjadi bagian dari kelompok. Kompetensi kerjasama menekankan pada peran sebagai anggota kelompok dan bukan sebagai pemimpin. Kelompok di sini dalam arti yang luas yaitu sekelompok individu yang bekerja sama menyelesaikan suatu tugas atau proses.

Pemilihan purposive sampling pada partisipan penelitian merupakan pemilihan subjek yang ada dalam posisi terbaik untuk memberikan informasi yang dibutuhkan. Dalam penelitian ini yang menjadi subjek penelitian adalah mahasiswa tingkat II di Polman Bandung sebanyak 119 orang yang terdiri dari 22 mahasiswi dan 97 mahasiswa.

\section{HASIL DAN PEMBAHASAN}

Hasil dari penelitian yang telah dilakukan terhadap 119 orang partisipan diperoleh gambaran secara umum berdasarkan keenam aspek yang diukur, yaitu motivation (mtv), flexibility (flx), willingness to learn (wtl), integrity (itg), relationship building (rlb) dan teamwork \& cooperation (twc).

Dengan kriteria penilaian yaitu 5 (baik sekali), 4 (baik), 3 (cukup), 2 (kurang) dan 1 (kurang sekali), maka tingkat soft skills dari mahasiswa dapat dilihat pada gambar 1 sebagai berikut:

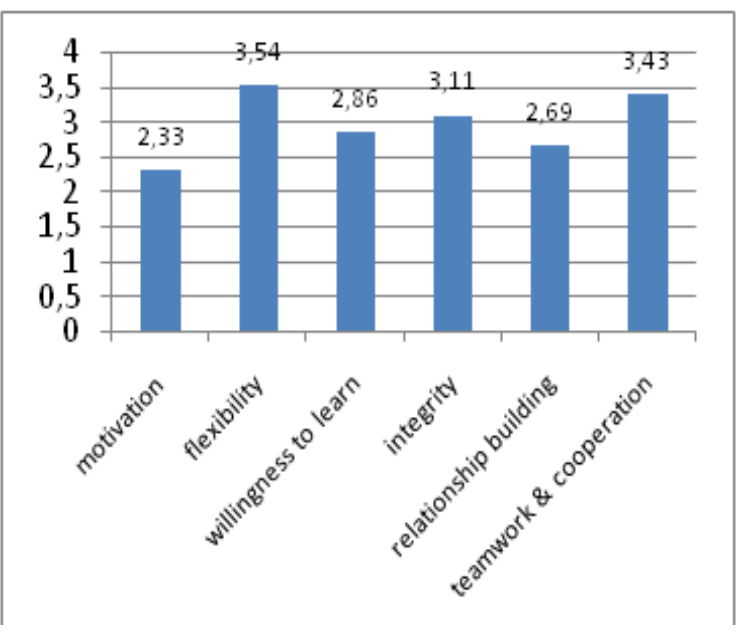

Gambar 1. Gambaran Profil Aspek Soft Skills

Berdasarkan hasil tersebut di atas, kemudian dihitung secara gabungan untuk memperoleh nilai rata-rata soft skills mahasiswa, dan hasil perhitungan skor rata-rata adalah $2,99 \approx 3$ yang berarti terletak pada kriteria penilaian cukup. Hal ini dapat dikatakan bahwa mahasiswa tingkat II Polman Bandung memiliki soft skills yang cukup baik untuk mendukung keberhasilan mahasiswa dalam memperlancar studi maupun bekal dikemudian hari dalam bekerja.

Selain itu dapat dilihat pula pada gambar 1 bahwa dari keenam aspek soft skills yang diukur, aspek flexilibity menempati urutan tertinggi dari nilai yang diperoleh partisipan penelitian dibandingkan aspekaspek yang lain, dengan nilai 3,54 dengan kategori diatas cukup. Hal ini berarti mahasiswa tingkat II Polman Bandung memiliki kemampuan yang cukup baik untuk beradapatasi dan belajar dengan efektif dalam situasi yang berbeda dengan berbagai individu maupun kelompok. Mereka sudah cukup mampu memahami dan menghargai pandangan yang berbeda dan bertentangan mengenai suatu isu, dapat menyesuaikan pendekatan berdasarkan situasi dan dapat menerima dengan mudah perubahan dalam berbagai kegiatan studi atau institusi dimana dia berada.

Nilai tinggi berikutnya terletak pada aspek teamwork \& cooperation dengan nilai 3,43 dengan kategori diatas cukup. Hal ini menunjukkan adanya keinginan untuk bekerja sama melalui suatu jalinan komunikasi dengan orang lain secara kooperatif dan menjadi bagian dari kelompok. 
Bukan bekerja secara terpisah atau saling berkompetisi. Kompetensi kerjasama menekankan pada peran sebagai anggota kelompok dan bukan sebagai pemimpin. Kelompok disini dalam arti yang luas yaitu sekelompok individu yang menyelesaikan suatu tugas atau proses tertentu. Masih dalam kategori diatas cukup baik adalah aspek integrity, yaitu mahasiswa mampu bertindak konsisten, komit serta menunjukkan kejujuran yang sesuai dengan nilai-nilai dan kebijakan institusi serta kode etik meskipun dalam keadaan yang sulit untuk melakukan hal ini. Nilai-nilai tersebut dapat berupa nilai moral, nilai masyarakat dan nilai kode etik atau akademis.

Dari keenam aspek soft skills yang diukur, masih terdapat tiga aspek yang menunjukkan hasil yang masih kurang baik, dapat dilihat pada gambar 1, nilai aspek-aspek tersebut masih di bawah 3 dengan kategori di bawah cukup baik yaitu aspek motivation, relationship building dan willingness to learn. Kurangnya as-pek motivation menunjukkan kurangnya energi dan dorongan untuk mau bekerja keras, belajar dengan baik dan bila perlu melampaui standar prestasi. Standar tersebut bisa berupa prestasi diri sendiri di masa lalu (improvement), ukuran objektif yang ditetapkan institusi, melebihi orang lain (competitiveness), sasaran yang menantang dan sesuatu yang belum pernah dilakukan oleh orang lain (innovation).

Sedangkan kurangnya relationship building berarti mahasiswa masih kurang mampu melakukan kegiatan untuk membangun dan memelihara jaringan, kontak dengan orang yang berguna atau yang mungkin dapat berguna dalam pencapaian tujuan studi. Kemampuan ini tidak hanya didasari oleh interpersonal skills saja namun juga termasuk di dalamnya terdapat unsur keyakinan diri dan kepedulian akan lingkungan sosial.

Aspek terakhir yang dinilai kurang juga adalah aspek willingness to learn, hal ini menunjukkan bahwa masih kurangnya kemauan mahasiswa untuk selalu ingin belajar yang diawali dengan adanya kurangnya kesadaran akan kebutuhan untuk mengembangkan diri, kemudian melalukan introspeksi diri akan kelebihan dan kekurangannya dengan melihat tuntutan yang selalu berubah dan meningkat. Tercakup di dalamnya adalah kurangnya usahausaha untuk mengembangkan diri, dengan mencari tahu cara-cara yang efektif untuk belajar dan kemudian menerapkannya hingga menyusun rencana pengembangan diri yang sistematis tersebut berikut caracara memonitor kemajuan dirinya.

Berdasarkan hasil di atas kemudian dilakukan pengujian terhadap perbedaan soft skills di antara perempuan dan lakilaki dan hasilnya menunjukkan bahwa jenis kelamin tidak memiliki peran yang signifikan terhadap penguasaan soft skills pada mahasiswa, seperti yang tampak pada gambar 2 di bawah ini.

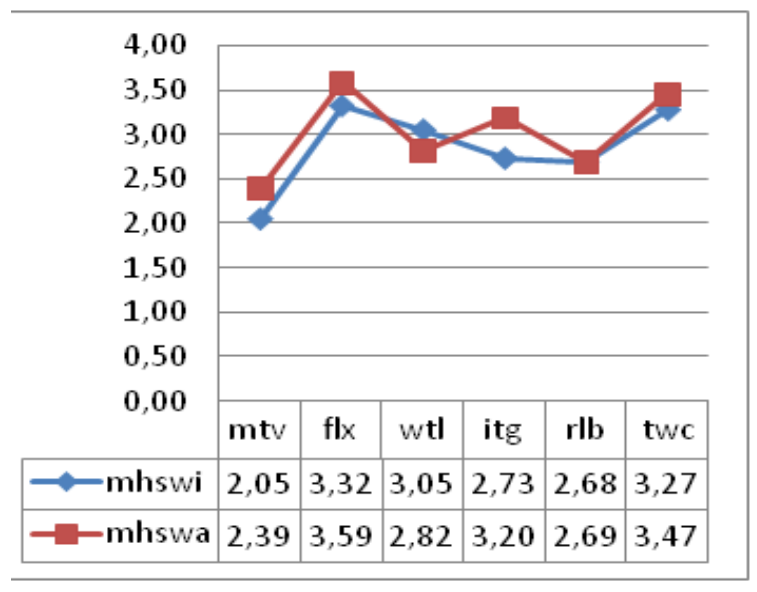

Gambar 2. Perbandingan soft skills berdasarkan jenis kelamin

Dari gambar di atas terlihat bahwa skor rata-rata dari setiap aspek soft skills mahasiswa dan mahasiswi yang diukur relatif tidak jauh berbeda atau dengan kata lain masih dalam rentang kriteria penilaian yang hampir sama. Hal ini menunjukkan bahwa tidak ada peran dari jenis kelamin dalam pengusaan soft skills pada mahasiswa. Baik perempuan maupun laki-laki memiliki kemampuan penguasaan soft skills yang hampir sama.

\section{SIMPULAN}

Dari hasil pengukuran soft skills tersebut di atas dapat disimpulkan bahwa gambaran umum soft skills mahasiswa tergolong cukup, yang berarti mahasiswa 
memiliki soft skills yang cukup baik untuk menunjang keberhasilan mereka dalam studi dan pekerjaannya di masa yang akan datang.

Berdasarkan skor yang diperoleh, dapat disimpulkan bahwa aspek flexibility merupakan aspek yang lebih dikuasai oleh mahasiswa dibandingkan kelima aspek yang lain yaitu motivation, willingness to learn, integrity, relationship building dan teamwork \& cooperation. Aspek flexibility ini memegang peranan dalam mengelola kemampuan untuk beradapatasi dan belajar dengan efektif dalam situasi yang berbeda dengan berbagai individu maupun kelompok. Mereka sudah cukup mampu memahami dan menghargai pandangan yang berbeda dan bertentangan mengenai suatu pendapat atau isu, serta dapat menyesuaikan pendekatan berdasarkan situasi dan dapat menerima dengan mudah perubahan dalam berbagai kegiatan studi atau institusi dimana dia berada.

Sedangkan aspek motivation merupakan aspek yang paling kecil yang dimiliki oleh mahasiswa dibanding aspekaspek yang lain. Hal ini perlu menjadi perhatian terutama bagi institusi pendidikan dan mahasiswa itu sendiri, mengingat tanpa adanya motivasi yang baik untuk belajar dengan baik dan bekerja keras maka akan lebih sulit untuk mencapai tujuan seperti yang diharapkan. Beberapa pembinaan bisa dilakukan baik oleh institusi maupun mahasiswa secara pribadi, misalnya dengan mengadakan beberapa kegiatan training tentang achivement motivation yang kemudian hasil dari training tersebut dapat dijaga keberlangsungannya oleh mahasiswa secara pribadi.

Dari hasil pengujian terhadap perbedaan soft skills di antara perempuan dan laki-laki menunjukkan bahwa jenis kelamin tidak memiliki peran yang signifikan terhadap penguasaan soft skills pada mahasiswa. Dengan kata lain penguasaan soft skills tidak tergantung oleh jenis kelamin, baik laki-laki maupun perempuan memiliki kesempatan yang sama dalam penguasaan soft skills ini.
Pengukuran soft skills yang diwakili oleh keenam aspek soft competency ini sudah cukup mewakili hasil pengukuran soft skills yang diperlukan oleh institusi Polman Bandung saat ini, namun tidak menutup kemungkinan perlu dikembangkan lagi tidak hanya dilihat dari keenam aspek tersebut mengingat dari karakter yang ingin dikembangkan yaitu jujur, cerdas, tangguh, dan peduli masih dapat digali lagi dalam beberapa aspek soft skills yang lain sesuai dengan perkembangan tuntutan pembinaan karakter mahasiswa di masa yang akan datang. Eksplorasi dari hasil penelitian, data yang sudah ada saat ini, serta masukan dari pakar dan alumni dapat dipakai sebagai pertimbangan untuk menentukan soft skills mana yang ingin ditingkatkan dan dikembangkan.

\section{DAFTAR PUSTAKA}

Barrick, Murray R., \& Michael K. 1991. The Big Five Personality Dimensions and Job Performance : A Meta Analysis. Personnel Psychology, 44, 1-26.

Cangelosi, B.R., \& Peterson, M.L. 1998. Peer teaching assertive communication strategies for workplace. (Clearinghouse No. CE078025). Montgomery, AL: Auburn University at Montgomery, School of Education. (Eric Document Reproduction Service No. ED427166).

Goleman, D. 1998. Working with Emotional Intelligence. New York : Bantam Books.

Marchand, A., Demers, A. \& Durand, P. 2005. Does work really cause distress? The contribution of occupational structure and work organization to the experience of psychological distress. Social Science \& Medicine, in press.

Mastuti, E. 2005. Analisis Faktor Alat Ukur Kepribadian Big Five (Adaptasi dari IPIP) pada Mahasiswa Suku Jawa. INSAN. Vol. 7, No. 3, Desember 2005. Robbins, S.P. 2001. Organizational Behavior $9^{\text {th }}$ Edition. New Jersey: Prentice Hall.

Undang-undang RI No. 20 tahun 2003 tentang Sistem Pendidikan Nasional

Widhiarso, W. 2009. Evaluasi Soft Skills dalam Pembelajaran. Melalui http:// widhiarso.staff.ugm.ac.id 